\title{
Subterranean systems provide a suitable overwintering habitat for Salamandra salamandra
}

\author{
Monika Balogová1 ${ }^{*}$, Dušan Jelić ${ }^{2}$, Michaela Kyselová ${ }^{1}$, and Marcel Uhrin ${ }^{1,3}$ \\ ${ }^{1}$ Institute of Biology and Ecology, Faculty of Science, P. J. Šafárik University, Šrobárova 2, 04154 Košice, Slovakia \\ ${ }^{2}$ Croatian Institute for Biodiversity, Lipovac I., br. 7, 10000 Zagreb, Croatia \\ ${ }^{3}$ Department of Forest Protection and Wildlife Management, Faculty of Forestry and Wood Sciences, Czech University of Life Sciences, \\ Kamýcká 1176, 16521 Praha, Czech Republic
}

\begin{abstract}
The fire salamander (Salamandra salamandra) has been repeatedly noted to occur in natural and artificial subterranean systems. Despite the obvious connection of this species with underground shelters, their level of dependence and importance to the species is still not fully understood. In this study, we carried out long-term monitoring based on the capture-markrecapture method in two wintering populations aggregated in extensive underground habitats. Using the POPAN model we found the population size in a natural shelter to be more than twice that of an artificial underground shelter. Survival and recapture probabilities calculated using the Cormack-Jolly-Seber model were very constant over time, with higher survival values in males than in females and juveniles, though in terms of recapture probability, the opposite situation was recorded. In addition, survival probability obtained from Cormack-Jolly-Seber model was higher than survival from POPAN model. The observed bigger population size and the lower recapture rate in the natural cave was probably a reflection of habitat complexity. Our study showed that regular visits are needed to detect the true significance of underground shelters for fire salamanders. The presence of larvae was recorded in both wintering sites, especially in bodies of water near the entrance. On the basis of previous and our observations we incline to the view, that karst areas can induce not only laying in underground shelters but also group wintering in this species. Our study highlights the strong connection of the life cycle of fire salamanders with underground shelters and their essential importance for the persistence of some populations during unfavourable conditions and breeding activity. In addition, the study introduces the POPAN and Cormac-Jolly-Seber models for estimating of population size, survival and recapture probability in wintering populations of the species, which could provide important information for species conservation.
\end{abstract}

Keywords: fire salamander, underground shelter, capture-mark-recapture method, population size, survival probability, recapture probability

Received 11 July 2016; Revised 25 February 2017 Accepted 1 March 2017

Citation: Balogová M., Jelić D., Kyselová M. and Uhrin M., 2017. Subterranean systems provide a suitable overwintering habitat for Salamandra salamandra. International Journal of Speleology, 46 (3), 321-329. Tampa, FL (USA) ISSN 0392-6672

https://doi.org/10.5038/1827-806X.46.3.2026

\section{INTRODUCTION}

Amphibians are ectothermic vertebrates dependent on external heat sources for maintaining the preferred body temperature (Willmer et al., 2000; Raske et al., 2012) and on humidity for the moist skin needed for respiration (Moore \& Sievert, 2001). The winter period represents for them a considerable challenge, because mortality caused by freezing, desiccation or predation (Linder et al., 2003; Wells, 2007) can be significant, especially in populations occupying a marginal habitat (Feder \& Burggren, 1992). Winter dormancy has evolved as a direct protective behavioural response to changing seasons, as it removes an animal from environments with adverse low temperatures which can cause its death (Pinder et al., 1992; Vitt \& Caldwell, 2013). In terms of reptiles and amphibians, overwintering is secondarily also a response to changes in resource availability (Gregory, 1982). Terrestrial amphibians usually overwinter in various wintering places, such as under rock outcrops, hollow trees, natural cavities found in clay deposits and gravel piles, or inside spaces under mats of vegetation (Wells, 2007; Vitt \& Caldwell, 2013). Some amphibians inhabit various extensive natural or artificial subterranean environments with a stable 
temperature and high humidity, such as caves or mines (e.g., Baumgart, 1981; Bressi \& Dolce, 1999), and some are even referred to as troglobionts with the entire life cycle linked to these habitats. This type of natural history is particularly evident in the families Proteidae and Plethodontidae. Proteidae includes six species, only one of which - Proteus anguinus from southeastern Europe - is troglobiotic, while Plethodontidae, the largest family of salamanders in the world, comprises more than 240 species, from which nine taxa are troglobiotic species from North America (Gunn, 2004; Gorički et al., 2012). However, most amphibians spend only a part of their lives in subterranean habitats intentionally or accidentally and are classified either as troglophiles or trogloxenes based on various criteria (Gunn, 2004). Furthermore, underground environments play an essential role as thermal refugia not only during winter but also for the persistence of some amphibians during drought and warm summer periods (e.g., Cimmaruta et al., 1999; Ficetola et al., 2012; Rosa \& Penado, 2013).

The fire salamander (Salamandra salamandra) is a widely distributed temperate European species inhabiting a broad range of habitats (Degani, 1996; Griffiths, 1996; Steinfartz et al., 2000). It has been repeatedly found during winter periods (OctoberApril) in various subterranean habitats across Europe and in some of them even several tens of adult individuals were aggregated (Feldmann, 1967; Baumgart, 1981; Bressi \& Dolce, 1999; Balogová \& Uhrin, 2014), but no evidence of cave adaptations was found in these salamanders. In addition, this amphibian exhibits strong fidelity to such wintering sites; therefore, wintering fire salamanders can be regularly found at the same place during subsequent winter periods (Böhme et al., 2003; Manenti et al., 2009; Balogová \& Uhrin, 2014). Several studies have also confirmed the importance of these shelters for breeding activity in this species even when surface water is available nearby (e.g., Manenti et al., 2009; Manenti et al., 2011; Gorički et al., 2012; Ianc et al., 2012; Manenti \& Ficetola, 2013; Limongi et al., 2015). It has furthermore been assumed that they play an important role as hiding places with lower temperature and higher humidity during the active season and as feeding habitats, because appropriate invertebrate prey often occurs at the entrances of these shelters (Uhrin \& Lešinsky, 1997).

Despite the obvious importance of underground shelters for this species and the fact that it commonly spends a substantial part of its life cycle inside them, the view regarding the dependence of the fire salamander on these habitats is still underestimated, and the classification of the fire salamander into categories of cave-dwelling animals is controversial in published sources. There is a visible gradual progression in considering this species to be trogloxenous (Baumgart, 1981) to rather more troglophilous (e.g., Kováč et al., 2014). In the current study, we focused on longterm monitoring of two fire salamander populations wintering in a natural cave and in an artificial gallery based on the capture-mark-recapture method (CMR). The objectives of this study were (1) to evaluate population parameters and breeding activity of our observed wintering populations; (2) to investigate which kind of subterranean habitat (in our case natural cave or artificial gallery) is probably more appropriate for the wintering of fire salamanders and monitoring of their population trends; and (3) to evaluate the level of importance of underground shelters for the investigated species and its dependence on them.

\section{MATERIAL AND METHODS}

The survey was conducted in two wintering sites in eastern Slovakia: a natural cave (Bobačka; Spišskogemerský kras Mts.; 4846.9'N 2006.3'E; $811 \mathrm{~m}$ a.1.) in the period December 2011 - February 2015 i.e., during four winters (December 2011 - March 2012 - 5 inspections, December 2012 - April 2013 - 6 inspections, November 2013 - April 2014 8 inspections, October 2014 - February 2015 5 inspections) and an artificial damp gallery (Tichá Voda; Volovské vrchy Mts.; 48 $46.2^{\prime} \mathrm{N}, 20^{\circ} 36.3^{\prime} \mathrm{E}$; $855 \mathrm{~m}$ a.1.) in the period November 2011 - February 2015 i.e., during four winters (November 2011 - April 2012 - 10 inspections, December 2012 - March 2013 - 2 inspections, December 2013 - January 2014 - 2 inspections, December 2014 - February 2015 2 inspections).

Bobačka Cave is a fluvial limestone cave with active water flow. It is 3,036 $\mathrm{m}$ long and $142 \mathrm{~m}$ deep (Kováč $\&$ Merta, 1991; Mikuš, 2000; Bella et al., 2007). The cave entrance (dimensions of $50 \times 80 \mathrm{~cm}$ ) is closed by metal bars that do not impede crossing of smaller animals. Height of cave ceiling varies from approximately $1 \mathrm{~m}$ up to more than $6 \mathrm{~m}$. Fire salamanders are annually wintering in the entrance corridor of ca. 20-30 m from the cave entrance only; no salamanders were recorded in deeper parts of the cave. This is an observation made during annual winter monitoring of bats conducted in almost the entire cave (Uhrin et al., 2010).

Tichá Voda Gallery is a horizontal gallery composed of a tangle of corridors on two levels with a total length of approximately 350 m (Matis \& Pjenčák, 2002). The corridors are approximately $2 \mathrm{~m}$ high and $1.3 \mathrm{~m}$ wide. Out of the total gallery length, we monitored only the parts where salamanders are annually wintering. These include the main entrance corridor and two lateral corridors. The main corridor is $113 \mathrm{~m}$ long with an easily accessible entrance $(1.7 \times 1.4 \mathrm{~m})$. While salamanders usually aggregate $23-33 \mathrm{~m}$ deep from the gallery entrance, the remaining individuals are dispersed throughout the corridor. Of the two side corridors, the first ends blindly after $8 \mathrm{~m}$ and the second is occupied by salamanders for the first 30 $\mathrm{m}$. Average temperatures during the winter period inside observed underground shelters were $8.5^{\circ} \mathrm{C}$ in December and $7^{\circ} \mathrm{C}$ in March in Bobačka Cave, and $6^{\circ} \mathrm{C}$ in Tichá Voda Gallery.

During the surveys, we carried out inspections by photographing all captured individuals and their subsequent release back into the wintering site. Individual identification was done later in the 
laboratory based on the database of photographs and codes of unique coloration on the dorsum of each individual (Opatrný, 1983). Despite the previous suggestion that the dorsal spot patterns could in this species change (Balogová et al., 2016), we assumed the reliability of this method and the absence of errors in identification based on the regular visits of the observed wintering sites. Each captured and recaptured individual was put into the dataset using binary capture categories $(1=$ captured, $0=$ not captured). Sex determination was based on the external morphology of the cloacae and the presence of a receptaculum seminis in females (Francis, 1934; Opatrný, 1983). The age structure of the populations was determined on the basis of total length of the individuals. Salamanders with total length of more than $15 \mathrm{~cm}$ were assigned to the adult stage, and smaller individuals were categorised as juveniles (cf. Baruš et al., 1992). Breeding activity was detected on the basis of the presence of larvae in the bodies of water at the wintering sites.

The obtained data did not reflect a simple CMR study, because we were not sampling the total population "superpopulation") but only a fraction that was wintering in the underground shelters ("wintering population"). Furthermore, migration of individuals from "superpopulation" outside into "wintering population" was very strong. The total population size estimate and survival of "wintering population" was calculated using a simple Jolly-Seber model (Jolly, 1965; Seber, 1965; Gotelli \& Ellison, 2013) modified according to the POPAN model, which takes migration into account (Cooch \& White, 2016). Further, we used the Cormack-Jolly-Seber (CJS) model (Cormack, 1964; Jolly, 1965; Seber, 1965) to estimate survival (Phi) and capture probability (p) for both wintering sites and all groups (females, males, juveniles). In contrast to the survival of "wintering population" derived from POPAN model, these parameters obtained from CJS model take in account whole "superpopulation". Four basic models $(\{\mathrm{Phi}(\mathrm{t}) \mathrm{p}(\mathrm{t})\} ;\{$ Phi $(.) \mathrm{p}(\mathrm{t})\} ;\{$ Phi(t) $\mathrm{p}()\} ;.\{$ Phi $()$. $\mathrm{p}()\}$.$) ( \mathrm{t}$ - time-dependent, (.) - constant through time) were developed for estimating survival probabilities from the two samples and for each of the three age and sex groups. The best-fitting model, based on the Model Likelihood, corrected Akaike's Information Criterion (AICc), differences in AICc value from the best model $(\triangle \mathrm{AICc}), \mathrm{AICc}$ Weights and Deviance (see Cooch \& White, 2002, for details), was presented for each group.

The models were implemented using the MARK program (White \& Burnham, 1999; Cooch \& White, 2016). In order to fit the model, we divided our continuous 4-year study period into four sampling intervals (winter periods), arbitrarily ranging from 1 October to 30 April. Between the intervals no sampling was done (spring-summer-autumn active period) and during wintering intervals between particular samplings varied in most cases (91\%) from one to five weeks (always lasting one day), in two cases (Tichá Voda Gallery) 8-9 weeks and in one case it was 6 weeks in the Bobačka Cave. Based on this method, 24 one-day sampling occasions for the Bobačka Cave and 16 for the Tichá Voda Gallery were conducted and included in the analysis. In the case of the Bobačka Cave all intervals were set to " 1 " (representing the number of months passed from last sampling) except the intervals 5,11 , and 19 , which were set to " 8 ". In the case of the Tichá Voda Gallery the same was done for intervals 10, 12, and 14 .

\section{RESULTS}

Overall we recorded 92 wintering salamanders $(27$ males, 29 females, 36 juveniles) in the Bobačka Cave and 56 (26 males, 18 females, 12 juveniles) in the Tichá Voda Gallery. In the Bobačka Cave we were able to catch 7.5 individuals on average $(8.2 \%$ of the total number; $\min =1, \max =22$ ) and in the Tichá Voda Gallery 14.8 fire salamanders per inspection $(26.4 \%$ of the total number; $\min =4$, $\max =24)$.

The total size of "wintering population" was estimated on average to be 148.8 individuals in the Bobačka Cave with a density of 3.7 individuals per $\mathrm{m}^{2}$ and 60.3 salamanders in the Tichá Voda Gallery with a density of 0.3 individuals per $\mathrm{m}^{2}$. Average survival of wintering individuals obtained by POPAN model was higher in males than females and juveniles in Bobačka Cave, but on the contrary it was higher in females than males and juveniles in the Tichá Voda Gallery (Table 1).

A completely non-time dependent model $\{$ Phi(.) $\mathrm{p}()$. was the best-fitting model (lowest AICc $=682.5293$ ) in all groups (females, males, juveniles) and in both wintering locations.

Using CJS model, we recorded higher survival probability in males than females and juveniles at both wintering sites (Bobačka Cave: males phi $=0.9795, \mathrm{SE}=0.0098 ;$ females - phi $=0.9488$, $\mathrm{SE}=0.0128 ;$ Tichá Voda Gallery: males - phi $=0.9864$, $\mathrm{SE}=0.0060 ;$ females - phi $=0.9785, \mathrm{SE}=0.0096$, juveniles - phi $=0.9710, \mathrm{SE}=0.0189)$. In contrast to this, recapture probability was higher in females (Bobačka Cave: males $-\mathrm{p}=0.0831, \mathrm{SE}=0.0170$, females $-\mathrm{p}=0.1485, \mathrm{SE}=0.0267$; Tichá Voda Gallery: males $-\mathrm{p}=0.4304, \mathrm{SE}=0.0360$, females $-\mathrm{p}=0.4394, \mathrm{SE}=0.0483$, juveniles $-\mathrm{p}=0.2513$, $\mathrm{SE}=0.0595)$. In addition, recapture probability was much higher in the Tichá Voda Gallery ( 43\% for males and females) than in the Bobačka Cave ( 8\% and 14\% for males and females, respectively). In particular, we recaptured certain individuals (11 salamanders) more than seven times in the Tichá Voda Gallery, but in the Bobačka Cave we noticed a lower recapture rate where half of the individuals (46 individuals) were not recaptured (see Fig. 1).

In terms of breeding activity, we recorded the presence of larvae in both localities. In the Tichá Voda Gallery this was recorded in early and late March. Females laid larvae into water bodies near the entrance or into puddles only a few centimetres deep, situated more than $20 \mathrm{~m}$ from the entrance (Fig. 2A). The latter was also the preferred location of adult individuals during the winter season in the gallery. In the Bobačka Cave larvae were present only in the water bodies of the entrance hall. 
Table 1. Estimates of population size, average survival and density of wintering individuals using the Jolly-Seber Popan model.

\begin{tabular}{|c|c|c|c|c|c|c|c|c|}
\hline & Average & \multicolumn{2}{|c|}{ CI 95\% } & $\begin{array}{c}\text { Average survival } \\
\text { [month] }\end{array}$ & $\begin{array}{c}\text { Surface } \\
{\left[\mathrm{m}^{2}\right]}\end{array}$ & $\begin{array}{c}\text { Density } \\
{\left[\mathbf{m}^{2}\right]}\end{array}$ & \multicolumn{2}{|c|}{ CI 95\% } \\
\hline \multicolumn{9}{|c|}{ Bobačka Cave } \\
\hline $\mathrm{F}$ & 36.7 & 31.5 & 52.2 & 0.9001 & 40 & 0.9 & 0.8 & 1.3 \\
\hline $\mathrm{M}$ & 34.9 & 29.4 & 53.3 & 0.9243 & 40 & 0.9 & 0.7 & 1.3 \\
\hline Juv & 77.2 & 46.6 & 196.4 & 0.8707 & 40 & 1.9 & 1.2 & 4.9 \\
\hline SUM & 148.8 & 107.5 & 301.9 & & 40 & 3.7 & 2.7 & 7.5 \\
\hline \multicolumn{9}{|c|}{ Tichá Voda Gallery } \\
\hline $\mathrm{F}$ & 20.4 & 18.4 & 33.9 & 0.9631 & 196 & 0.1 & 0.1 & 0.2 \\
\hline $\mathrm{M}$ & 26.2 & 26 & 32.9 & 0.9552 & 196 & 0.1 & 0.1 & 0.2 \\
\hline Juv & 13.6 & 12.2 & 24.4 & 0.9124 & 196 & 0.1 & 0.1 & 0.1 \\
\hline SUM & 60.3 & 56.6 & 91.2 & & 196 & 0.3 & 0.3 & 0.5 \\
\hline
\end{tabular}

Average number of individuals - Average, 95\% confidence interval - CI 95\%.

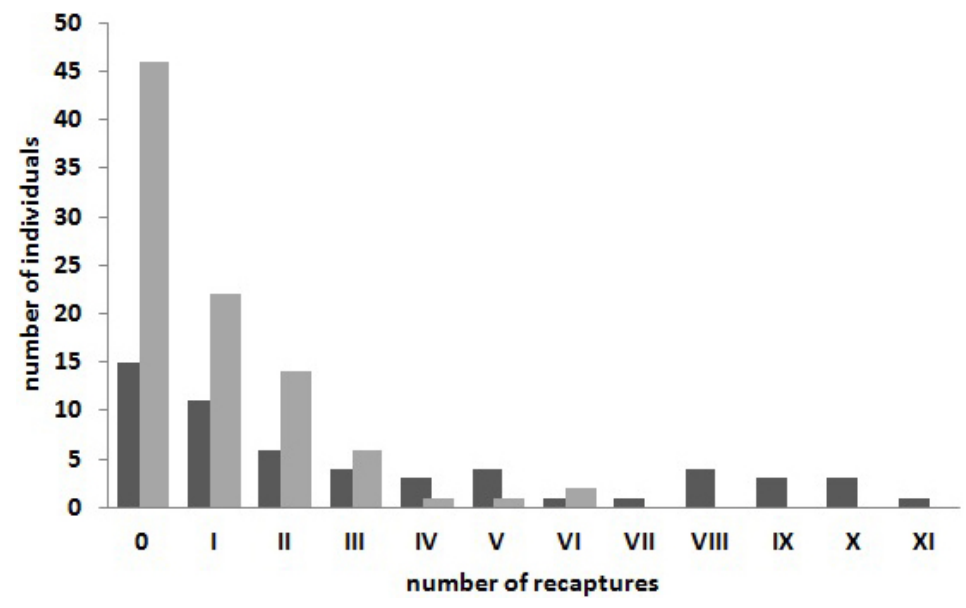

Fig. 1. Recaptures of wintering individuals in both wintering sites. Dark gray Tichá Voda Gallery, light gray - Bobačka Cave.

\section{DISCUSSION}

\section{Population data}

The difference between the real number of wintering individuals found in an underground shelter and estimate population size predicted by the POPAN model was significantly higher in the Bobačka Cave than in the Tichá Voda Gallery, where difference amounted to only a few individuals. The higher number of estimated individuals compared to the real situation in the natural cave could be caused by the unavailability of salamanders for trapping. In contrast to the gallery (Fig. 2B), salamanders could be hidden in deep crevices of the cave and thus unseen by the observers.

Our findings are consistent with those of Wagner et al. (2011) in two European anurans Bufo (=Pseudepidalea) viridis and Hyla arborea. They observed higher "superpopulation" estimates than simple population counts and suggested that the "superpopulation" approach is a useful population size estimator for amphibian species with "prolonged" breeding. Their study also showed that superpopulation estimates are unbiased but that accuracy can be low when either survival or detection probabilities (or both) are low. A similar superpopulation approach was also used for other taxa, such as the stream-breeding frog (Mixophyes fleayi) (Newell et al., 2013, Quick et al., 2015), the common toad (Bufo bufo) (Loman \& Madsen, 2010), tadpoles of the Iberian midwife toad (Alytes cisternasii) (Ribeiro \& Rebelo, 2011), the snakenecked turtle (Hydromedusa tectifera) (Lescano et al., 2008) and asynchronously breeding birds (Williams et al., 2011).

Estimate of population size and density using CMR data and appropriate models was carried out also in other cave-dweling species occurring in North America such as the grotto salamander (Eurycea spelaea) (Fenolio et al., 2014), the big mouth cave salamander (Gyrinophilus palleucus necturoides) (Niemiller et al., 2016) or the Tennessee cave salamander (Gyrinophilus palleucus) (Huntsman et al., 2011). Appropriate models were probably chosen according to their lifestyle. These amphibians are closely tied to subterranean habitats and they did not form surface populations. It means that there was no migration between outside and cave population as we observed in our study. Therefore, the authors decided to use simple open and in one case closed population models in contrast to the super-population approach.

The survival and recapture probabilities for Salamandra salamandra were constant over time in all groups and both wintering locations, but the abundance can vary independently over the years. In fire salamander populations in western Germany and southern Switzerland, Schmidt et al. (2007) and Schmidt \& Schaub (2014) recorded similar monthly survival probabilities consistently higher than 0.9 . Furthermore, no pronounced differences in mortality within seasons were detected, with any survival differences observed between summer and winter.

It is clear that not all salamanders living in the study areas come to overwinter in underground shelters. However, in the case of survival probability this could imply that some individuals preferred to use the monitored cave and gallery as wintering sites over and over through the years. In general, males had a higher survival probability than females and juveniles, which may relate to their lifestyle and body fitness. Compared to females, who have to migrate in order to lay larvae, and to juveniles, who disperse into the field, males usually do not engage in such risky behaviour. Also, female fitness and ability to escape from predators are generally lower during gravidity. Regular using of wintering sites during winter period by salamanders could also imply higher survival 

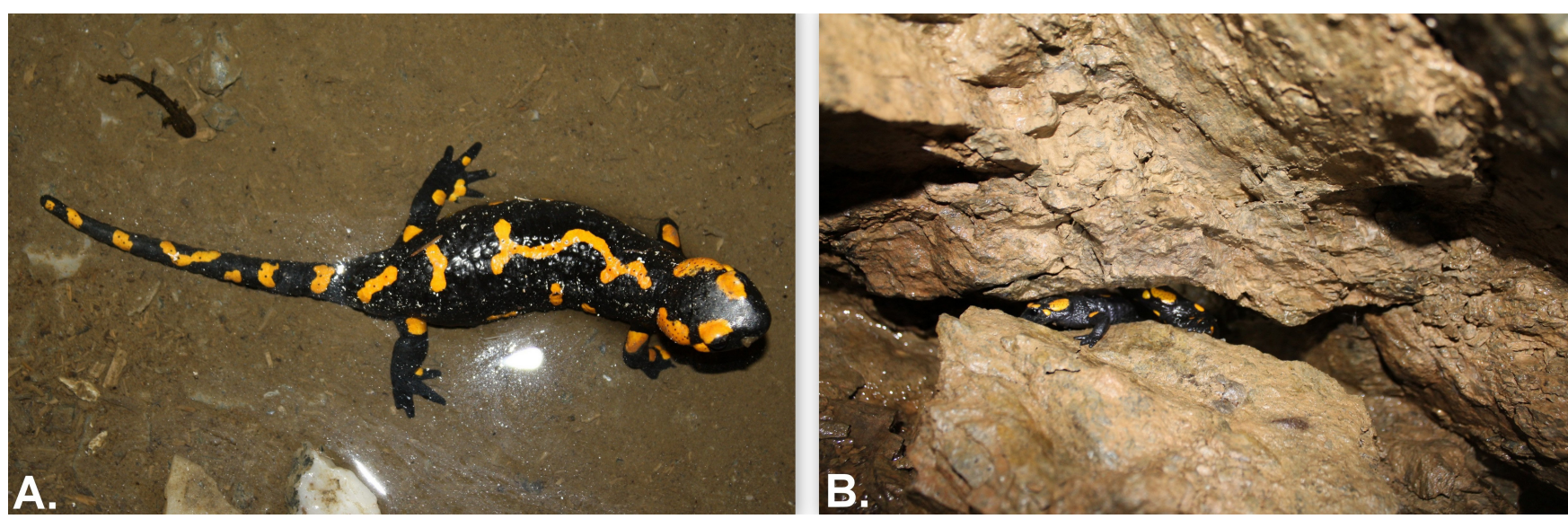

Fig. 2. Examples of using of underground shelters by Salamandra salamandra. A) Female laying larvae into a puddle in the Tichá Voda Gallery;

B) Adult individual hidden in fissure in the Tichá Voda Gallery.

probability obtained from CJS model compared with survival from POPAN model.

The recorded higher recapture probability in the Tichá Voda Gallery (Fig. 1) was probably a reflection of the fact that the overall population was smaller and almost completely marked. Furthermore, it could be also explained by already mentioned better visibility of individuals during monitoring due to higher homogeneity of the walls in contrast to the cave. Generally, we assumed that higher heterogeneity of habitat can cause greater underestimating of the wintering population of the fire salamander and thus more inaccurate results during monitoring of population trends. Our mark-recapture study showed that regular visits are necessary for detecting the true significance of underground shelters for this species, because occasional inspections can be greatly misleading and lead to underestimating in this respect.

Recapture probability was higher in females in both wintering sites compared to males and juveniles. The reason could be that females were more available for capture during our inspections. Balogová \& Uhrin (2014) observed that most females were located freely in the corridor inside the Tichá Voda Gallery while males preferred crevices. The free position of females during wintering could probably be the result of searching for suitable bodies of water for laying larvae.

The higher number of recorded individuals as well as the higher estimate of population size in the Bobačka Cave in comparison with the artificial gallery implies that in our case the natural cave was a more appropriate habitat for wintering of the fire salamander. This could be the result of the already mentioned higher heterogeneity of this wintering site, which provided more suitable conditions with a lot of hidden places for wintering salamanders, or higher suitability of the outdoor environment which population inhabits outside the winter period. The high density of individuals in the Bobačka Cave reflects their occupancy of a smaller surface area than in the artificial underground shelter.

On the basis of presence of larvae in both wintering sites, we are inclined to agree with previous claims that the laying of larvae in underground shelters is not an accidental phenomenon but on the contrary, can be even favoured in karstic areas (Bressi \&
Dolce, 1999; Manenti et al., 2011). The occurrence of fire salamander larvae in underground springs was recorded also in Romania (Ianc et al., 2012), Italy (Bressi \& Dolce, 1999; Razzetti et al., 2001; Manenti et al., 2011) and Slovakia (Uhrin \& Lešinský, 1997; Balogová \& Uhrin, 2014, 2015) as well as in Portugal in the subspecies S. s. gallaica (Rosa \& Penado, 2013).

Despite suggestion that larval development in this environment can require more than eight months, it can also have big advantages, such as absence of predators, the constant thermal environment and water level, which allows development even during winter (Manenti et al., 2009). Except the laying of larvae in March in the Tichá Voda Gallery, we also recorded the presence of larvae in November and January of the following year in another artificial gallery situated in the eastern part of Slovakia (Balogová, unpublished data). These findings correspond with the study of Manenti et al. (2009), who observed laid larvae in November and in May-April and December of the subsequent year. Manenti et al. (2011) assumed that accessibility of shelters and richness of macrobenthos belongs among the most important variables determining the presence of larvae. They also observed that the frequency of larvae was higher in water bodies near the cave entrances. Except for the presence of macrobenthos, which was not evaluated, the results of our study are in line with these predictions.

\section{Ecology in subterranean habitats}

To our knowledge there is one study by Schmidt et al. (2005) that used wintering aggregations of the fire salamander for demographic analyses using markrecapture data and appropriate models. However, most of the previous studies often provide inaccurate information in this regard or simple population counts (e.g., Uhrin \& Lešinský, 1997; Bressi \& Dolce, 1999; Ianc et al., 2012). Studies that have observed wintering populations regularly are very rare (e.g., Feldmann, 1967; Baumgart, 1981; Schmidt et al., 2005).

On the basis of the real number of wintering salamanders and estimates of population size we assume that the presented underground shelters belong among the significant wintering sites for the fire salamander in Europe. Generally, we incline to the view that karst areas induce not only laying in 
underground shelters but also group wintering in this species.

Importance of underground shelters for fire salamanders proves also the length of a period of their subterranean life lasting at least 180 days a year during wintering. However, also during their epigeous life they are hidden most of the time in various subterranean microhabitats (Baruš et al., 1992; Zwach, 2009) or even in the extensive underground shelters (e.g., Uhrin \& Lešinský, 1997; Manenti et al., 2009).

Fire salamander activity was recorded in an epigeous habitat from a minimal temperature of $3^{\circ} \mathrm{C}$ and high humidity (Seifert, 1991; Böhme et al., 2003). The peak of activity varied in localities in a range of temperatures from 6 to $15^{\circ} \mathrm{C}$ (e.g., Bas Lopez, 1982; Blab, 1986; Seifert, 1991; Kuzmin, 1995). Thiesmeier (1988) recorded the main migration of females during the period of larvae deposition in night time temperatures of at least $6^{\circ} \mathrm{C}$ in North RhineWestphalia, Germany. These recorded temperatures are in accordance with the average temperatures measured inside our observed underground shelters. These environments are therefore an appropriate habitat with suitable ambient temperatures and high humidity levels for this species.

On the basis of the close connection of some fire salamander populations to a subterranean habitat, we are of the opinion that the species is more troglophilous than trogloxenous according to standard Schiner-Racovitza classification, because it can breed and spend substantial part of its life cycle in underground roosts (Trajano, 2012). According to reviewed classification (Sket, 2008), the fire salamander best fits the category of subtroglophiles i.e., species that are intimately associated to the cave environments, but requiring the epigean habitats during some period or to complete some biological function. Furthermore, a stronger connection of some amphibian species to caves than hitherto suggested by their assigned biospeleological categories was observed by Lunghi et al. (2014). For example, several epigeous amphibian species usually considered as trogloxenes or accidentals were frequently found in caves and had strong association to cave features.

Rather than the more popular term „hibernation“, known especially in mammals, a more appropriate term for winter dormancy of fire salamanders in extensive underground environments of western and central Europe is probably „brumation“ (e.g., Catenazzi, 2016) which even could have different physiological patterns (Wilkinson et al., 2017). During brumation vertebrate poikilotherms are not asleep, they are less active and can survive a long time without food (Textbook Equity, 2014). Generally, amphibians experience an energy deficit during brumation and must therefore store energy during favourable periods of energy acquisition. In urodelans, lipids are stored in abdominal fat bodies, carcass and tail. Their highest amount is usually before winter dormancy and minimal after breeding in the spring and early summer (Fitzpatrick, 1976). We already confirmed that adult fire salamanders show mobility during wintering (Balogová \& Uhrin,
2014) and we also observed no feeding on invertebrate prey (Balogová et al., 2015), although various species of invertebrate prey were previously detected at monitored wintering sites (e.g., Kováč et al., 2002; own unpublished observations). Salamanders had only skin remains in their stomach contents, which could represent another energy source for this species during wintering alongside the lipid storage. This stomach item can be easily obtained without high energy loss in contrast to active hunting of prey, which is often substantially limited underground in comparison to epigeous environment (Culver et al., 2004; Hüppop, 2012). Therefore, we assume that salamanders cannot afford to spend energy on active hunting during this unfavourable time. An alternative food resource in the subterranean habitat was also recorded for example in the carnivorous species Eurycea spelaea, in which coprophagy during underground time was observed (Fenolio et al., 2006). Last but not least, it is also possible that salamanders survive this dormancy period completely without eating because it is possible that undigested food during brumation could rot in the stomach and cause internal bacterial infection and possibly death. Several authors warned keepers of some reptile species against this situation (e.g., Mader, 2006; Mong \& Tintle, 2013). Stopped food intake in winter has also been recorded in another amphibian species (e.g., Banas et al., 1988; Kuzmin, 1992).

\section{CONCLUSIONS}

The strong connection of the life cycle of fire salamanders with natural and artificial underground shelters and their essential importance for the persistence of some populations during unfavourable conditions and for their breeding activity was confirmed. Although these subterranean systems provide suitable environmental conditions for the investigated amphibian species, it must leave them for hitherto unidentified causes.

This study communicates the size, survival and recaptures probability of two populations of the fire salamander in close connection with underground shelters. Through investigation of regularly wintering group aggregations of the fire salamander using CMR method and population models (POPAN and CormacJolly-Seber models), important information for species conservation was collected. We assume that the proposed models may also be generalized to the long-term monitoring of other amphibian populations with a similar type of aggregated wintering as the fire salamander.

More than twice bigger population size in natural cave in comparison with the artificial gallery implied that in our case the natural cave was probably a more suitable habitat for wintering of the fire salamander as the possible result of the higher heterogeneity and suitability of this microhabitat or higher suitability of the outdoor environment which population inhabits outside the winter period.

Regular visits using the mark-recapture method are important for a reliable estimate of the number 
of wintering individuals in underground shelters, which could otherwise be significantly distorted by occasional inspections, particularly in natural caves. Furthermore, we propose that higher habitat heterogeneity can cause greater underestimation of the wintering population of fire salamanders.

\section{ACKNOWLEDGMENTS}

We are grateful to G. Knižacká, P. Orendáš, L. Macková, L. Feher, S. Potkányová, N. Pipová, K. Varcholová, E. Maxinová, M. Rendoš and L. Kováč for their help in locating wintering sites and in collecting data. We would like to thank very much all reviewers for their helpful comments and suggestions on the previous versions of the manuscript.

\section{REFERENCES}

Balogová M. \& Uhrin M., 2014 - Patterns of the wintering of fire salamanders (Salamandra salamandra) in an artificial underground roost. North-Western Journal of Zoology, 10 (1): 128-132.

Balogová M., Kyselová M. \& Uhrin M., 2016 - Changes in dorsal spot pattern in adult Salamandra salamandra (Linnaeus, 1758). Herpetozoa, 28 (3/4): 167-171.

Balogová M., Miková E., Orendáš P. \& Uhrin M., 2015 Trophic spectrum of adult Salamandra salamandra in the Carpathians with the first note on food intake by the species during winter. Herpetology Notes, 8: 371-377.

Banas J.A., Loesche W.J. \& Nace G.W., 1988 Classification and distribution of large intestinal bacteria in nonhibernating and hibernating leopard frogs (Rana pipiens). Applied and Environmental Microbiology, 54: 2305-2310.

Baruš V., Oliva O., Král B., Opatrný E., Rehák I., Rocek Z., Roth P., Špinar Z. \& Vojtková L., 1992 - Obojživelníci - Amphibia. Academia, Praha, 340 p.

Bas Lopez S., 1982 - La actividad de la salamandra, Salamandra salamandra (L.), en Galicia. Doñana Acta Vertebrata, 9: 41-52.

Baumgart G., 1981 - Observations sur l'hibernation de quelques amphibiens dans les anciennes mines vosgiennes: salamandre tachetée (Salamandra salamandra Linné, 1758), grenouille rousse (Rana temporaria Linné, 1758) et crapaud commun (Bufo bufo Linné, 1758). Aquarama, 58 (2): 42-45, 72; 59 (3): 46-48, 72.

Bella P., Hlaváčová I. \& Holúbek P., 2007 - Zoznam jaskýn̆ Slovenskej republiky (stav k 30. 6. 2007). Slovenské múzeum ochrany prírody a jaskyniarstva, Liptovský Mikuláš, 364 p.

Blab J., 1986 - Biologie, ökologie und Schutz von Amphibien. Kilda, Greven, 152 p.

Böhme W., Grossenbacher K. \& Thiesmeier B., 2003 Handbuch der Reptilien und Amphibien Europas, Band 4/IIB: Schwanzlurche (Urodela) IIB, Salamandridae III: Triturus 2, Salamandra. Aula Verlag, Wiesbaden, 400 p.

Bressi N. \& Dolce S., 1999 - Osservazioni di anfibi e rettili in grotta. Rivista di Idrobiologia, 38 (1-3): 475-481.

Catenazzi A., 2016 - Ecological implications of metabolic compensation at low temperatures in salamanders. PeerJ, 4: e2072. https://doi.org/10.7717/peerj.2072

Cimmaruta R., Forti G., Nascetti G. \& Bullini L., 1999 Spatial distribution and competition in two parapatric sibling species of European plethodontid salamanders. Ethology Ecology \& Evolution, 11: 383-398.

https://doi.org/10.1080/08927014.1999.9522821
Cooch E. \& White G., 2002 - Using MARK- A gentle introduction. Electronic Book.

http://www.phidot.org/software/mark/docs/book/.

Cooch E. \& White G., 2016 - Using MARK- A gentle introduction. Electronic Book.

http://www.phidot.org/software/mark/docs/book/.

Culver D.C., Christman M.C., Sket B. \& Trontelj P., $2004-$ Sampling adequacy in an extreme environment: species richness patterns in Slovenian caves. Biodiversity and Conservation, 13: 1209-1229. https://doi.org/10.1023/B:BIOC.0000018153.49280.89

Degani G., 1996 - Salamandra salamandra at the southern limit of its distribution. Laser Pages Publishing, Jerusalem, $154 \mathrm{p}$.

Feder M.E. \& Burggren W.W. (Eds.), 1992 - Environmental physiology of the amphibians. University of Chicago Press, Chicago, 472 p.

Feldmann R., 1967 - Nachweis der Ortstrene des Feuersalamanders, Salamandra salamandra terrestris Lacépède, 1788, gegenüber seinem Winterquartier. Zoologischer Anzeiger, 178: 42-48.

Fenolio D.B., Graening G.O., Collier B.A. \& Stout J.F., 2006 - Coprophagy in a cave-adapted salamander; the importance of bat guano examined through nutritional and stable isotope analyses. Proceedings of the Royal Society B, 273: 439-443. https://doi.org/10.1098/rspb.2005.3341

Fenolio D.B., Niemiller M.L., Bonett R.M., Graening G.O., Collier B.A. \& Stout J.F., 2014 - Life history, demography, and the influence of cave-roosting bats on a population of the grotto salamander (Eurycea spelaea) from the Ozark Plateaus of Oklahoma (Caudata: Plethodontidae). Herpetological Conservation and Biology, 9 (2): 394-405.

Ficetola G.F., Pennati R. \& Manenti R., 2012 - Do cave salamanders occur randomly in cavities? An analysis with Hydromantes strinatii. AmphibiaReptilia, 33: 251-259.

https://doi.org/10.1163/156853812X638536

Fitzpatrick L.C., 1976 - Life history patterns of storage and utilization of lipids for energy in amphibians. American Zoologist, 16: 725-732. https://doi.org/10.1093/icb/16.4.725

Francis E.T.B., 1934 - The anatomy of the salamander. Clarendon Press, Oxford, 482 p.

Gorički Š, Niemiller M.L. \& Fenolio D.B., 2012 Salamanders. In: White W.B. \& Culver D.C. (Eds.), Encyclopedia of caves. $2^{\text {nd }} E d$. Elsevier Academic Press, Amsterdam, p. 665-676. https://doi.org/10.1016/B978-0-12-383832-2.00098-0

Gotelli N.J. \& Ellison A.M., 2013 - A primer of ecological statistics. Second edition. Sinauer Associates, Massachusetts, $613 \mathrm{p}$.

Gregory P.T., 1982 - Reptilian hibernation. In: Gans C. \& Pough F.H. (Eds.), Biology of the Reptilia. Volume 13. Physiology D. Physiological Ecology. Academic Press, New York, p. 53-154.

Griffiths R.A., 1996 - Newts and salamanders of Europe. T. \& A.D. Poyser, London, 188 p.

Gunn J. (Ed.), 2004 - Encyclopedia of caves and karst science. Fitzroy Dearborn, New York, 902 p.

Huntsman B.M., Venarsky M.P., Benstead J.P. \& Huryn A.D., 2011 - Effects of organic matter availability on the life history and production of a top vertebrate predator (Plethodontidae: Gyrinophilus palleucus) in two cave streams. Freshwater Biology, 56: 1746-1760. https://doi.org/10.1111/j.1365-2427.2011.02609.x

Hüppop K., 2012 - Adaptation to low food. In: White W.B. \& Culver D.C. (Eds.), Encyclopedia of caves (2 $\left.{ }^{\text {nd }} E d.\right)$ Elsevier Academic Press, Amsterdam, p. 1-9. https://doi.org/10.1016/B978-0-12-383832-2.00001-3 
Ianc R., Cicort-Lucaciu A.S., Ilies D. \& Kovács E., 2012 - Note on the presence of Salamandra salamandra (Amphibia) in caves from Padurea Craiului Mountains, Romania. North-Western Journal of Zoology, 8 (1): 202-204.

Kováč L \& Merta K., 1991 - Najnovšie objavy v jaskyni Bobačka. Slovenský kras, 29: 179-183.

Kováč L., Luptáčik P. \& Mock A., 2002 - Článkonožce (Arthropoda) jaskyne Bobačka (Muránska planina). In: Uhrin M. (Ed.), Výskum a ochrana prírody Muránskej planiny 3, Správa NP Muránska planina, Revúca, p. 141-145.

Kováč L., Elhottová D., Mock A., Nováková A., Krištůfek V., Chroňáková A., Lukešová A., Mulec J., Košel V., Papáč V., Luptáčik P., Uhrin M., Višňovská Z., Hudec I., Gaál L. \& Bella P., 2014 - The cave biota of Slovakia. State Nature Conservancy SR, Slovak Caves Administration, Liptovský Mikuláš, 192 p.

Kuzmin S.L., 1992 - Feeding ecology of the Caucasian salamander (Mertensiella caucasica), with comments on life history. Asiatic Herpetological Research, 4: 123-131.

Kuzmin S.L., 1995 - Die Amphibien Russlands und angrenzender Gebiete. Westarp- Spektrum, Magdeburg - Heidelberg, 274 p.

Lescano J.N., Bonino M.F. \& Leynaud G.C., 2008 Density, population structure and activity pattern of Hydromedusa tectifera (Testudines- Chelidae) in a mountain stream of Córdoba province, Argentina. Amphibia-Reptilia, 29: 505-512. https://doi.org/10.1163/156853808786230497

Limongi L., Ficetola G.F., Romeo G. \& Manenti R., 2015 Environmental factors determining growth of salamander larvae: a field study. Current Zoology, 61: 421-427. https://doi.org/10.1093/czoolo/61.3.421

Linder G., Sparling D.W. \& Krest S.K. (Eds.), 2003 Multiple stressors and declining amphibian populations: evaluating cause and effect. Society of Environmental Toxicology and Chemistry, Boca Raton, 282 p.

Loman J. \& Madsen T., 2010 - Sex ratio of breeding common toads (Bufo bufo) - influence of survival and skipped breeding. Amphibia-Reptilia, 31 (4): 509-524. https://doi.org/10.1163/017353710X524705

Lunghi E., Manenti R. \& Ficetola G.F., 2014 - Do cave features affect underground habitat exploitation by nontroglobite species? Acta Oecologica, 55: 29-35. https://doi.org/10.1016/j.actao.2013.11.003

Mader D.R., 2006 - Reptile medicine and surgery. Second edition. Saunders Elsevier, St. Louis, 1264 p.

Matis Š. \& Pjenčák P., 2002 - Zimoviská netopierov Volouských vrchov II. Vespertilio, 6: 333-336.

Manenti R. \& Ficetola G.F., 2013 - Salamanders breeding in subterranean habitats: local adaptations or behavioural plasticity? Journal of Zoology, 289: 182-188.

https://doi.org/10.1111/j.1469-7998.2012.00976.x

Manenti R., Ficetola G.F., Bianchi B. \& De Bernardi F., 2009 - Habitat features and distribution of Salamandra salamandra in underground springs. Acta Herpetologica, 4 (2): 143-151.

Manenti R., Ficetola G.F., Marieni A. \& De Bernardi F., 2011 - Caves as breeding sites for Salamandra salamandra: habitat selection, larval development and conservation issues. North Western Journal of Zoology, 7 (2): 304-309.

Mikuš M., 2000 - Nové paleoúrovne jaskyne Bobačka. Spravodaj, 31 (2): 9-13.

Mong D. \& Tintle J., 2013 - Honduran milksnakes. A collective history of Honduran milksnakes for the hobbyist. ColdBlooded Publishing, LLC, USA, 172 p.
Moore C.M. \& Sievert L.M., 2001 - Temperature-mediated characteristics of the dusky salamander (Desmognathus fuscus) of southern Appalachia. Journal of Thermal Biology, 26: 547-554.

https://doi.org/10.1016/S0306-4565(00)00052-8

Newell D.A., Goldingay R.L. \& Brooks L.O., 2013 Population recovery following decline in an endangered stream-breeding frog (Mixophyes fleayi) from subtropical Australia. PLoS ONE, 8 (3): e58559.

https://doi.org/10.1371/journal.pone.0058559

Niemiller M.L., Glorioso B.M., Fenolio D.B., Reynolds R.G., Taylor S.J. \& Miller B.T., 2016 - Growth, survival, longevity, and population size of the big mouth cave salamander (Gyrinophilus palleucus necturoides) from the type locality in Grundy County, Tennessee, USA. Copeia, 104 (1): 35-41.

https://doi.org/10.1643/OT-14-197

Opatrný E., 1983 - Individuelle Identifikation vom Feuersalamander, Salamandra salamandra (Linnaeus, 1758), nach den Hautpigmentzeichnungen. Acta Universitatis Palackianae Olomucensis, Facultas Rerum Naturalium, Biologica, 78 (23): 107-111.

Pinder A.W., Storey K.B. \& Ultsch C.R., 1992 - Estivation and hibernation. In: Feder M.E. \& Burggren W.M.I. (Eds.), Environmental physiology of the amphibians. Univelsity of Chicago Press, Chicago, p. 250-274.

Quick G., Goldingay R.L., Parkyn J. \& Newell D.A., 2015 - Population stability in the endangered Fleay's barred frog (Mixophyes fleayi) and a program for long-term monitoring. Australian Journal of Zoology, 63 (3): 214-219.

https://doi.org/10.1071/ZO14106

Raske M., Lewbart G.A., Dombrowski D.S., Hale P., Correa M. \& Christian L.S., 2012 - Body temperatures of selected amphibian and reptile species. Journal of Zoo and Wildlife Medicine, 43: 517-521.

https://doi.org/10.1638/2011-0244R.1

Razzetti E., Bonini L. \& Barbieri F., 2001 - Riproduzione in grotta di Salamandra salamandra e Salamandrina terdigitata negli Appennini settentrionali. Pianura, 13: 181-184.

Ribeiro J. \& Rebelo R., 2011 - Survival of Alytes cisternasii tadpoles in stream pools: a capture recapture study using photo-identification. Amphibia-Reptilia, 32 (3): 365-374.

https://doi.org/10.1163/017353711X584186

Rosa G.M. \& Penado A., 2013 - Rana iberica (Boulenger, 1879) goes underground: subterranean habitat usage and new insights on natural history. Subterranean Biology, 11: 15-29. https://doi.org/10.3897/subtbiol.11.5170

Schmidt B,R., Feldmann R. \& Schaub M., 2005 Demographic processes underlying population growth and decline in Salamandra salamandra. Conservation Biology, 19: 1149-1156.

https://doi.org/10.1111/j.1523-1739.2005.00164.x

Schmidt B.R., Schaub M. \& Steinfartz S., 2007 - Apparent survival of the salamander Salamandra salamandra is low because of high migratory activity. Frontiers in Zoology, 4 (19): 1-7.

https://doi.org/10.1186/1742-9994-4-19

Schmidt B.R., Itin E. \& Schaub M., 2014 - Seasonal and annual survival of the salamander Salamandra salamandra salamandra. Journal of Herpetology, 48 (1): 20-23. https://doi.org/10.1670/12-056

Seifert D., 1991 - Untersuchungen an einer ostthüringischen Population des Feuersalamanders (Salamandra salamandra). Artenschutzreport, 1: 1-16. 
Sket B., 2008-Can we agree on an ecological classification of subterranean animals? Journal of Natural History, 42: $1549-1563$.

https://doi.org/10.1080/00222930801995762

Steinfartz S., Veith M. \& Tautz D., 2000 - Mitochondrial sequence analysis of Salamandra taxa suggests old splits of major lineages and postglacial recolonizations of central Europe from distinct source populations of Salamandra salamandra. Molecular Ecology, 9: 397-410.

https://doi.org/10.1046/j.1365-294x.2000.00870.x

Textbook Equity, 2014 - College biology (volume 2 of 3). Textbook Equity, California, 515 p.

https://www.textbookequity.org/\%E2\%96\%

BAcollege-biology-volume-2/

Thiesmeier B., 1988 - Zur ökologie und Populations dynamik des Feuersalamanders (Salamandra salamandra terrestris Lacépéde, 1788) im Niederbergischen Land unter besonderer Berücksichtigung der Larvalphase. Unpublished PhD dissertation, University GHS Essen, $182 \mathrm{p}$.

Trajano E., 2012 - Ecological cassification of subterranean organisms. In: White W.B. \& Culver D.C. (Eds.), Encyclopedia of caves. (2 $2^{\text {nd }}$ Ed.). Elsevier Academic Press, Amsterdam, p. 275-277.

https://doi.org/10.1016/B978-0-12-383832-2.00035-9

Uhrin M. \& Lešinský G., 1997 - Mechanism of occurrence of amphibians in underground spaces in Slovakia: preliminary data evaluation. Proceedings of the $12^{\text {th }}$ International congress of Speleology, La Chaux de fonds Switzerland, 3: 325-327.
Uhrin M., Benda P., Obuch J. \& Urban P., 2010 Changes in abundance of hibernating bats in central Slovakia (1992-2009). Biologia, 65 (2): 349-361. https://doi.org/10.2478/s11756-010-0020-Z

Vitt L.J. \& Caldwell J.P., 2013 - Herpetology: an introductory biology of amphibians and reptiles (4th $E d$.). Academic Press. Waltham, 776 p.

Wagner N., Pellet J., Lötters S., Schmidt B.R. \& Schmitt T., 2011 - The superpopulation approach for estimating the population size of "prolonged" breeding amphibians: Examples from Europe. Amphibia-Reptilia, 32: 323-332. https://doi.org/10.1163/017353711X579768

Wells K.D., 2007 - The ecology and behavior of amphibians. Chicago University Press, Chicago, 1148 p.

White G.C. \& Burnham K.P., 1999 - Program MARK: survival estimation from populations of marked animals. Bird Study, 46 (Supp1.): 120-138.

https://doi.org/10.1080/00063659909477239

Wilkinson A., Hloch A., Mueller-Paul J. \& Huber L., 2017 - The effect of brumation on memory retention. Scientific Reports, 7: 40079. https://doi.org/10.1038/srep40079

Williams K.A., Frederick P.C. \& Nichols J.D., 2011 - Use of the superpopulation approach to estimate breeding population size: an example in asynchronously breeding birds. Ecology, 92 (4): 821-828.

https://doi.org/10.1890/10-0137.1

Willmer P., Stone G. \& Johnston I., 2000 - Environmental physiology of animals (2 $2^{\text {nd }} E$.). Blackwell Science, Oxford, $768 \mathrm{p}$.

Zwach I., 2009 - Obojživelníci a plazy České republiky. Grada Publishing, a.s., Praha, 496 p. 